\title{
BREAKING THE CODE: STRATEGIES OF ALCOHOL ADDICTS
}

\author{
Tatiana Argounova-Low, Platon Sleptsov
}

\begin{abstract}
The article addresses the problems related to alcohol abuse and its medical treatment called 'coding'. The treatment by 'coding' subjugates alcoholics to a relationship between them and other more dominant agents. Despite such pressure being very powerful, we argue that alcoholics develop their strategies and ways to manoeuvre and manipulate these dominant relationships. The article explains why treatment by coding is often ineffective.
\end{abstract}

Keywords: alcohol, alcoholism, coding, Sakha (Yakutia)

\section{INTRODUCTION}

This article presents a new approach to a problem that has existed for a long time. This paper highlights issues around alcohol abuse and its treatment in Yakutsk, Sakha (Yakutia). In this paper we focus on the treatment generally known as 'coding' (kodirovanie), and analyse some personal stories regarding such treatment. In the stories that we listened to and followed, we observed a certain pattern of behaviour in alcohol-dependent people and their responses to treatment. Such observations gave us the possibility to interpret these patterns as certain stratagems used by alcoholics.

Going back to Yakutsk after a long interval, one experiences a storm of personal stories, which for this study became a gateway for understanding the effects of alcoholism and alcohol-related consequences, which had become commonplace in the last few years. Friends, relatives, acquaintances, neighbours - everyone seems to have a distressing story to tell about alcohol-related problems in their families. These stories, often heartbreaking, become part of the narrative in Yakutsk: an acquaintance who had to wear a thick layer of make-up to cover bruises on her face and arms - traces of her drunken husband's violence; another story told by a furious female whose husband was robbed of a large sum of cash while he was drinking, on the way to another city to purchase a new car; an elderly disabled mother who had to cope with the alcoholism of her son, her sole carer. Narratives like these ones are most vocal and most heard. 
Alongside accounts of divorces and accidents, there are recurring stories about attempts to beat alcoholism, curb it and undergo treatment. Yet again, these stories are often narrated by a family member: an exuberant wife or a mother telling of the successful treatment of her husband or son. More often than not, these are stories of repetitive treatments, happening again and again. It seemed a recurrent pattern with many alcohol-dependent people: being coded - drinking freely - being treated again. We decided to look into this pattern and offer our understanding of the situation and a possible explanation as to why the coding offered to alcoholics is often ineffective.

While interviewing persons who identify themselves as alcoholics, we have realised that in public discourse on alcohol abuse the voice of an alcoholic remains unheard most of the time. Bestowed with guilt, the alcohol-dependant people are not given a chance to speak out. In this article we decided to retain voices of people whom we interviewed and thus to give them an opportunity to participate in this discourse, present their narratives, and demonstrate their agency.

Both authors have long been fascinated with the theme of alcohol dependence and its treatment, particularly with its effects on the family. We have carried out participant observation as well as longitudinal interviews with various people who suffer from alcohol addiction, and their family members. The names of these people have been changed, as have some of their details, to protect their anonymity.

\section{CURRENT SITUATION IN SAKHA (YAKUTIA)}

Drinking patterns among Sakha fit into stereotypes of native drinking in other parts of the world, especially in the North. And just like the remote Arctic places that Hugh Brody describes, these patterns of drinking can be illustrated with the same "eruptions of violence, chronic social disarray, and mindless disregard for all that people are supposed to hold sacred - children are neglected, homes burned down, friends are attacked" (Brody 1977: 33). Medical practitioners often explain high alcohol dependence among native people by a low tolerance to alcohol, which is a result of their biological or genetic make-up. We are inclined to disagree, following Brody (1977), Spicer (1997), and Samson (2003), who opined that there are different social and cultural explanations for native drinking habits.

According to the information provided by the SakhaPress information agency, in 2011 there were 23,019 people who suffered from alcohol dependence from the total 958,528 people in the Republic of Sakha (Yakutia), and every year the 
number of alcohol-dependent people increases by approximately 5\%. In 2012 about 30,000 residents were registered as having alcohol dependence and suffering from alcohol-related psychosis (SakhaPress 2013). These numbers, of course, are not precise, as they indicate only registered patients who sought help from accredited services.

An internet site that provides consultation to people suffering from alcohol addiction revealed the seriousness of the problem with alcohol. From 481 people who responded to a questionnaire on the website, $34.7 \%$ replied that they had tried all possible methods to treat their alcoholism but nothing had helped. The rest of the respondents were convinced that alcohol addiction could be treated in hospital or with the help of private practitioners, including healers and shamans (Patrov 2010).

Indeed, the growing number of clinics and private practitioners offering a cessation of alcohol dependence is obvious in Yakutsk. It is almost impossible to provide an exact number of existing clinics offering help as such practitioners are not necessarily formally registered. Frequent advertisements in the newspapers, on television and the Internet make it obvious that such services are in great demand. We visited a number of clinics operating in the city, and remain under the impression that anti-alcohol treatment has turned into very profitable business enterprise. At present, five narcological hospitals and 30 narcological clinics operate in the republic with 54 psychiatrists specialising in narcology. In Krasnaya Yakutia (Red Yakutia, a narcological hospital in Yakutsk) alone, more than 3,500 patients are admitted and treated annually. And this number continues to grow (Tumusov 2011). Many movements, non-governmental organisations and political figures in the republic are campaigning towards a reduction in sales and banning access to alcohol altogether. And this is why this fight is hard to win.

\section{ALCOHOL AND THE STATE}

In her impressive study, Patricia Herlihy (2002) presents a history of the use of vodka and alcohol in late Imperial Russia and the politics that surrounded its production and consumption. Using historical data and statistics, she correlates the production of vodka and alcohol and the state monopoly thereof. Alcohol production was always one of the priorities for the state, for alcohol production, sales and high taxes on alcoholic drinks constituted one of the main revenue items in the Russian state budget. The problem of alcohol, however, concerned many medics and psychiatrists, and in the 1920s some experts already articulated alcoholism as 'the disease of our country' (ibid.: 36). Being 
of 'strategic importance' for the state, the question of rampant alcoholism has yet to be resolved.

Vladimir Bekhterev of the Psycho-Neurological Institute in St. Petersburg, the leading expert in alcohol studies in Russia in the 1920s, found a way out of this conundrum by suggesting a formula of moderate consumption of alcohol and making the statement that "capitalism, not alcohol, is "the fundamental evil of our era" (ibid.: 49). This was a convenient formulation for the state; presented in this way, alcoholism was a disease of consciousness, the mind, and the body.

"The body is directly involved in a political field; power relations have an immediate hold upon it; they invest it, mark it, train it, torture it..." (Foucault 1995 [1975]: 25). Such an interpretation of alcoholism and the perception of alcoholics, their bodies and their minds has become part of what Foucault calls the "political technology of the body" (ibid.: 26). Indeed, alcoholism, together with juvenile delinquency, crime and other disturbing social phenomena, was given a consistent ideological explanation and as 'a disease of capitalism' it had to be removed or at least separated from society (Efron 1960; Korolenko et al. 1994). Directives of the Soviet of People's Commissars in 1926 highlighted "compulsory treatment of alcoholics who constitute a social danger", and on the whole "social and psychological pressures for treatment were powerful" (Efron 1960: 312). The prophylactic anti-alcoholism work of the clinics was to highlight the destructive effects of alcohol as being incompatible with Soviet morality (ibid.: 313).

With this formulation the state was able to carry on with the production of alcoholic drinks, mainly vodka. "Social problems, and alcoholism in particular, according to official Soviet ideology are the products of a diseased and disorganised economy and society, i.e. of capitalism" (Field 1955: 105). Indeed, already in 1934 the Communist Party announced that socialism in the country had been achieved and capitalism eliminated, and the problem with alcoholism in the Soviet Union had been eradicated (Transchel 2006: 153). Since the problem of alcoholism had been 'solved', the production of vodka was increased and was now in the controlling hands of the central government. Such measures undeniably contributed to increasing alcoholism in the country but were explained by the reminants of capitalist consciousness that clouded the minds of some Soviet citizens. Allegedly, by 1940, the sales of alcoholic drinks were higher than those of meat, vegetables and fruit put together (Herlihy 2002: 154). From then on the state combated drunkenness at work and in public places by administrative measures.

The notion of alcoholism thus received a peculiar inflection similar to the notions of insanity and madness in Foucault's analysis (1989: 62). The notion implied the perception of alcoholism as an ideological crime and treatment 
involved the police, in addition to medical staff and psychologists. Vytrezviteli (infamously known as sobering-up stations) and labour rehabilitation centres (LTP) were run by police forces (Solomon 1989: 264; Transchel 2006: 155). People caught drunk in public places were placed in sobering-up stations for the night (Efron 1960: 312). The punishment for drinking was not only a fine; it also included obligatory notifications sent to the authorities and employers. A public notice with the name of a person, address and work place was displayed on a public notice-board accompanied by a cartoon mocking the drunkard. The whole incident resembled a public show trial.

Similar attitudes continued throughout the Soviet period and by the late 1960s the rhetoric of the elimination of alcoholism in the country became part of the hegemonic discourse of communist ideology (Yurchak 2003: 480-481). The split between ideological performance and its representation meant that stiff ideological clichés were produced, the slogans wrapped and induced through perpetuation at congresses, meetings, and posters, but the meaning of the slogan was emptied in the process or even before that. "Pianstvu Boi" (We will beat drunkenness) in reality had little meaning and the production of alcoholic drinks meanwhile continued to increase.

In their discussion on the lasting effects of the Soviet hegemony, Kharkhordin (1999) and Yurchak (2003) point to a dichotomy between official and hidden selves of the Soviet citizen. The official self would be present at meetings and would formally disapprove alcoholics. At the same time the hidden intimate would indulge in alcohol consumption, possibly straight after an anti-alcohol meeting. This created an effect of hidden alcoholism: from fear of being chastised or of punitive sanctions, many alcoholics went underground and carried on without the much needed treatment (Korolenko et al. 1994: 1273-1274).

With Gorbachev's ascent to power in 1985, the attitude to alcohol, its perception and treatment changed drastically. In the first two months in his new role Gorbachev adopted a resolution entitled On Measures to Overcome Drunkenness and Alcoholism (Herlihy 2002: 154). Alcohol became less easily available: the age limits were raised, opening hours for the sale of alcohol amended and vineyards were obliterated or converted for the production of soft fruit juices. In the same year, monthly alcohol rations per household were introduced to limit general consumption. Vodka was in short supply and temporarily turned into a currency; bottles of vodka purchased with coupons were used as payment for manual labour to plumbers and electricians, who were pleased to receive such payment in kind. Gorbachev's campaign also increased the amount of homebrewed alcohol. A quick alcoholic drink was made by fermenting sugar and yeast in large glass jars. Plastic gloves, instead of the lid, would stand upright waving in the air, signalling the readiness of the home brew. The drink was known by 
the popular name "Hello to Gorbachev". All in all, this anti-alcohol campaign revealed how important alcohol was for the country's coffers. Gorbachev himself admitted that his anti-alcohol campaign contributed to a 49 billion rouble deficit in revenue, allegedly on a scale comparable to the Chernobyl disaster (Korolenko et al. 1994: 1271).

So the anti-alcohol campaign failed, as did the Soviet Union, and later market economy conditions brought the relationship to alcohol in Russia to another extreme. Heavy alcohol advertising, availability and cheap prices took the alcohol problem to new heights, above other social issues. Yet, unlike in the past, there was none of the obligatory moralistic preaching, no public meetings and no propaganda about the harmful effects of alcohol. From a public issue that society combated, although ostensibly, alcoholism reverted to the hidden domain, where alcoholics and their families had to deal with it on their own.

\section{CODE FEAR}

The cure for alcoholism in the Soviet Union was associated with a method of treatment introduced by Alexander Dovzhenko, a psychiatrist and psychotherapist. Although the method of hypnosis had been known in Russia since 1904, it was Dovzhenko who took it further, developing and adopting the method for group therapy (Herlihy 2002: 46). Our aim is not to evaluate the effectiveness of this form of treatment, but to focus on the mechanism of the treatment and investigate our interviewees' attitudes and approaches towards encoding.

Much can be said about the personality of Alexander Dovzhenko, who certainly exploited his authority and influence to establish unconditional belief in the effectiveness of the treatment and his unique abilities as a doctor (Fleming et al. 1994: 360). The hypnotic séances were almost theatrically set, with suspended silences and a dramatically intimidating atmosphere. An old documentary depicts Doctor Dovzhenko during one of his séances. In a darkened room, a spotlight is centred on the imposing figure of the doctor in his white gown, slowly pronouncing every single word. Dovzhenko starts the process of treatment that he termed 'encoding', which was based on instilling fear in a person (Ivanov 2012). In this process of non-invasive lobotomy, an injected seed of fear into a person's mind was to govern all his future actions.

Coding relates to the method widely known as stress psychotherapy and, in Dovzhenko's interpretation, involved three stages. During the first stage the doctor selected, interviewed, and prepared the patients. The second stage involved a séance of hypnotic therapy that stressed the doctor's role in the treatment. Dovzhenko's crucial phrase: "During this hypnotic séance I will insert in your 
brain an anti-alcoholic, anti-narcotic psychic code" was to convince his patients that a stable centre in their brain would prevent cravings for alcohol in the future (Fleming et al. 1994: 360). The third stage was the 'encoding'. The doctor closed the eyes of the patient and pressed a spot on the head until it produced pain and sprayed ethyl chloride into the patient's mouth, which produced various somatic symptoms. The practitioner 'encoded' the patient for a certain period of time chosen by the patient. The session ended with the patient signing the forms to state his or her full understanding of the consequences (ibid.). At the end of the treatment Dovzhenko used to pronounce his most important phrase of the treatment: "You drink - you die" (Vyp'esh - umresh'). The fear of death instilled in the brain of the patient was the very code that was to prevent the patient from drinking.

An accidental discovery of the anti-alcoholic properties of a chemical compound changed the treatment procedure. In 1946, at a car manufacturing plant in France, it was observed that the men who were engaged in rubber vulcanisation developed an aversion to alcohol. Tetramethylthiruram disulfide, also referred to as thiram, when inhaled, produced a sensation of alcohol aversion and since then it has been widely used as a basis for a great variety of alcoholaversive drugs (Anticol, Antabuse, Esperal). Administering these drugs, now widely used in Russia, causes severe adverse reactions when combined with alcohol, ranging from breathlessness to nausea and vomiting. The association with unpleasant reactions and the fear of them induces alcohol cessation.

A great variety of medical treatments for alcohol addiction spiralled from Dovzhenko's technique, but they all have one common aspect - they use the fear of death as a method of treatment. In all anti-alcohol treatments a therapist administers a substance to convince the patient that drinking might lead to their death. The causes are not normally clearly explained to the patient, which makes the fear even more profound. Patients whom we have interviewed were not provided with full information about these drugs, most of them were simply threatened by adverse harmful effects or even death to stop them drinking.

The process of treatment and insertion of a code, as well as the overall manipulation of the mind and body, serves to illustrate Foucault's notion of the "political technology of the body" (1995 [1975]) and Certeau's "inscriptions of the law on the body" (1984: 139). To inscribe discipline on people's bodies, "the scriptural apparatus of modern discipline" uses a variety of tools that can also be reserved for later use. These tools are made for restricting, confining, disciplining, and punishing the body (ibid.: 131). Our case study adds another method to the panoply of ways and methods for disciplining, restricting the body, and its overall "zombification" (Magalif 2011). 


\section{PERSONAL STORIES}

What follows are narrations of events, some recollections as shared with us by three informants. We think these stories are important and illustrative, as they reveal the ways alcohol-addicted people subvert decisions about their treatments and also reveal the factors that influence this decision-making.

\section{Artem}

As our main informant, Artem felt it was important to take part in the research and answer our questions about his alcohol dependence. He made a special effort to talk us through it, explain things and make certain aspects clearer for us. Having been friends for a while, we were familiar with his personal life over a long period. His youth in the 1960s-70s was filled with the relaxed ideological climate, music of the Beatles and partying, and drinking was a significant part of his growing up. He twice committed crimes while being drunk and was sentenced both times.

In the summer of 2011 we witnessed Artem and his family members after a serious car accident that happened when he was returning from work. He had drunk at work with his colleagues and was several times over the limit when driving home. He failed to negotiate a sharp bend and flew off the road into a broad and low ditch. He had a remarkable escape, with only a few cuts on his forehead; his car, however, was beyond repair.

It was either his lucky escape or the fact of losing the car that prompted Artem's decision to stop drinking again (zaviazat'). Later that evening he was sitting in front of us, plasters covering the cuts on his face, still slightly drunk and high from what had happened. He kept repeating the details of the incident, frequently stressing the fact that he did not have a car. His car, relatively new and costing a substantial amount of money, had been bought with contributions from family members. Now, with his older daughter sitting next to him, Artem was ashamed and feeling guilty, but, above all, sad at the inconceivable thought of walking or taking public transport.

As the evening progressed into night, the withdrawal symptoms started kicking in and Artem's mood changed to more depressed, quiet, and hostile. His older daughter, afraid of further developments, invited a private practitioner, who advertised post-binge detoxification on the Internet. The cost of treatment, approximately $£ 50$, was discussed and it was decided that Artem's daughter would cover the expense. That night after the treatment she held a vigil and, as prescribed, would give him the next instalment of sleeping tablets and water 
to continue the detoxification process. In the morning Artem, miserable, but without a headache, made his way to work by bus.

It was made clear to Artem that no members of the family would contribute to a new car if he continued to drink. Five days later, determined and completely dry, he got to the Narcological Centre to be coded. He had been there many times before. On the way, and in anticipation, he kept telling us about the procedure, stressing the physical side of the experience: injection, slight sickness, heat in the stomach area. "But afterwards," he says, "it is good, such a freedom, no desire to drink at all. Anybody could drink in front of me and I would not care."

It was obvious that Artem was familiar with the centre and its methods. He recognised the female doctor from his previous visits; however, she did not acknowledge him. While the doctor explained, Artem kept interrupting, saying that he knew the procedure from his previous visits. Finally, when he went to the cashier to pay a sum equivalent to $£ 60$, he asked if there was a discount for regular customers, to which the cashier retorted rather crossly.

The doctor asked Artem about the desired length of the coding. Artem's initial proposition was a year and a half, but the doctor increased it to two and a half years. Artem had to repeat after her the length of the intended time. He mentioned his preference to undergo treatment anonymously, merely for the reason to avoid appearing on the police and insurance records.

The nurse administered two injections, both in the area of Artem's upper back. He reported an unpleasant feeling and a slightly painful sensation of heat in his body and around his stomach. Artem stayed lying in bed for an hour, deep in his thoughts, sighing heavily from time to time. Before we left the room, the nurse explained to Artem the negative effects of drinking again. These explanations were rather vague, non-specific, but they contained a clear message about adverse effects: medicine reacting with alcohol would destroy the liver; its functions would degrade; the irreversible destructive processes could lead to a lethal end. As proof of her warning, the nurse pointed to two large glass jars in the room: both containing liver specimens with blisters and ulcers, an illustration of cirrhosis of the liver.

While we sat on a bench to let Artem recuperate, we silently observed people walking in through the door of the Narcological Centre. An elderly gentleman brought a younger man, possibly his son; a young woman with a man, her husband; a woman, about 40, on her own. At some point the young man surreptitiously escaped and his father started to erratically scurry along the corridor, reluctant to believe that his son would not be coded this time. When we left the clinic, it got busier in the corridor with people about to get coded.

The sociality that alcohol creates is difficult to replace; quitting drinking is often perceived and admitted by alcoholics themselves as a predicament. 
People who stay dry for a certain period often report a feeling of isolation and loneliness. So maintaining sobriety is difficult and going back to drinking is regarded as a re-union with drinking associates and friends (Brody 1977; Samson 2003). For Artem, sociality is probably one of the main reasons for drinking. Even if he stays dry, his colleagues' and friends' beckoning gradually becomes overpowering and he goes back to his usual drinking. The patterns become clear and repeat themselves more often: he is sober and with a new job, under pressure from his family, mainly his grown-up children. Artem never abstains for the length of the time he is coded for; it is several months until he cannot stand the loneliness and isolation any longer. He creates new connections, gains new drinking associates and regains old friends. This lasts until he loses his job due to alcohol. Then he spends time drinking heavily on borrowed money without a job, the pressure from his family increases and after a while he is forced to go to the clinic again.

\section{Kostia}

A gregarious, charming and fun-loving man, Kostia likes socialising and most of his friends are his drinking associates. Like Artem, he belongs to the generation for whom alcohol and being drunk were part of growing up. He started drinking a lot more recently, and on several occasions disappeared from home for weeks. Eventually, Kostia's wife threatened that she would leave him unless he underwent treatment.

In this case, drinking and the sociality that comes with it actually imply employment. Working in a creative industry, Kostia's colleagues are happy to share work contracts and assistance. Being at the workshop, doing jobs, often collectively, implies heavy drinking sessions. Conversely, staying sober, avoiding his normal circles after treatment and confining himself to home, means a lack of information about job opportunities, a lack of potential contracts, and money. Kostia, due to insistence from his wife, got encoded, as it suits both him and his wife to abstain for a period of time. However, sooner or later, disgruntled by his own idleness, Kostia goes to his friends, where commissioning contracts and thus payments are available. In this pattern money and drinking are in stark contrast to the lack of a job, money and sobriety.

Paul Spicer has argued about the (dys)functional approach to drinking that highlighted complex positive and negative aspects of native drinking (Spicer 1997: 307). Drinking is a very pleasurable activity for determined drinkers and that is why they are often guilt-free about their drinking (Brody 1977: 39). Another functional aspect of drinking is that it is an activity creating 
or re-affirming social connectedness between those who drink. This aspect of sociality, as a rule, implies egalitarianism: “There is one guy who drinks with us regularly; when he quits, he despises us, becomes arrogant, and thinks he is better than us. But a few days or weeks later he is back drinking with us." Kostia's quote here stresses the social and egalitarian aspect of drinking and explains why quitting drinking is understood as an attempt to lift oneself above others (Spicer 1997: 317). It is due to this profoundly social nature of drinking that quitting becomes a difficult task. Due to the necessity to socialise, as well as the necessity to earn money, Kostia has worked out his own strategy that allows for periodical drinking and staying sober.

\section{Nikolai}

Sceptical, with a sarcastic smile, Nikolai belongs to a younger generation. Now in his mid-thirties, he has been steadily drinking for ten years. Nikolai is divorced from his wife due to his alcohol addiction and admits to being an alcoholic. His drinking bouts can last for weeks, and afterwards, crapulent, sick, and without money, he turns up at his mother's house. Here he recuperates and, usually with financial and moral help from his mother, he arrives at the clinic to get encoded. Nikolai has held a series of jobs from which he either walked out himself or was fired.

Sitting at the table with the local newspaper open on the vacancies section, a mobile phone in his hand, he searches for short-term contracts. Short-term contracts might be a hindrance to many, but they are an advantage to Nikolai, for they are conveniently short and accommodate all his requirements. He quickly finds a suitable job, and after a quick phone call, submits his updated $\mathrm{CV}$ to the company to start his new job just a few days later.

Upon completion of his contract and getting all the money in one lump sum, he is free to indulge in drinking until he uses up all the money. On the insistence of his mother he tries the hospital treatment in Krasnaya Yakutia, where he stays for the whole duration of 21 days, receiving treatment. Nikolai gets sober again for a period of time, but after a few months he goes back to his social circles, where he gets the attention and appreciation of his friends and the cycle starts all over again.

Alternating short-term job contracts and sobriety with drinking periods for some is the sign of a lack of willpower and control. On the other hand, we argue that it is strategic thinking on Nikolai's part in order to accommodate his addiction. The fact that Nikolai gets coded but does not last long, is interpreted 
by his relatives as 'sorvalsia' (lost a grip), implying lack of inner strength and the fact that overall circumstances and alcohol were more powerful than him.

Alcoholics, like our main informants, often find themselves under pressure from family members, circumstances or economic demands to stop drinking. It is required of them to contribute to the family, and society demands they stick to the rules. However, there is also a strong obligation to stick to the other social circle: social ties and drinking associates. The coding in this scenario then is a way to appease the 'official' self, only to return later to the 'hidden intimate'.

The pattern of pressure, followed by treatment and then by a dry period, is repeated over and over again, and the relationship between dominance and order on the one hand and subversion and resistance on the other becomes apparent. People whom we interviewed were able to adapt to such demands and steer between the outside pressures and their own desires. This adaptation can be considered as the response of alcoholics to demands from the outside, but it also is a manipulation of certain situations (e.g. Artem securing money for a new car if gets encoded). We argue that these strategies for alcoholics, developed out of necessity or carefully calculated, are the reason for their multiple treatments by coding.

\section{BREAKING THE CODE}

It has now been established that treatment for alcohol dependence in the Soviet Union was an element of ideological subjugation on the state's part. Manipulation of the body and understanding it within the system of punishment, confinement, and correction brings us to the point, stressed by Foucault (1995 [1975]: 26), that the power that is exercised on the body should be considered within the ideas of strategies, tactics and manoeuvres of both the dominant and dominated. Such an execution of power inexorably brings confrontations, conflicts and struggles and produces the hidden transcript, according to Scott (1990: 27). Often such counter-struggles are not 'official' but 'hidden', following arguments made by Scott (1990), Kharkhordin (1999), and Yurchak (2003).

During the period of abstinence, alcoholics are controlled by the code of fear that has been 'inserted' in their brain. From that moment and for the rest of their lives, abstinence is a yardstick against which their actions are measured. There is the presence of the watchful eye, of a doctor, wife, mother, and the refrain of a nagging question: would they resist the temptation to drink? Would they endure? The interviewees we have chosen for this study underwent repeated treatment: two of them had encoding done more than twice, and one interviewee had been coded more than six times. For their partners and family members, 
these repeated treatments attest to the alcoholics' absence of strength, low willpower and lack of determination to continue with sobriety. Such repeated coding in vernacular corresponds to the word 'sorvalsia' associated with falling, flying off, or losing grip.

Although alcoholics themselves often talk in the same idiom of being weak and unable to see it through, it transpires from their interviews that there is a considerable element of deliberation. In each case we have observed how coding for alcoholism, although dominantly presented and administered, is sabotaged. We have offered some examples, merely as illustrations, of how alcoholics subvert the suggested, and imposed, coding. We argue that by breaking the code alcoholics demonstrate their agency and gain their autonomy.

Agency as a capacity to act presupposes some resistance. Laura Ahearn (2001: 115) warns us against a too simplistic understanding of agency and that it should not be equated to resistance. We consider that oppositional agency for this particular case study would be a plausible and productive way to analyse this piece of research.

Power is everywhere; not because it embraces everything, but because it comes from everywhere. And "Power," insofar as it is permanent, repetitious, inert, and self-reproducing, is simply the over-all effect that emerges from all these mobilities, the concatenation that rests on each of them and seeks in turn to arrest their movement. (Foucault 1978: 93)

\section{CONCLUSION}

In this article we have aimed to address alcoholism, an urgent social issue that has serious negative effects on the native community in Yakutsk, Sakha (Yakutia). We have used observation techniques and interviews to gather and evaluate the situation related to treatment of alcohol by coding.

Historically, alcohol production and distribution have always been in the hands of authorities and governments. Drinking was ideologised and from the perception of alcoholism as an ideological weakness, a disease of the mind, all consequent attitudes and aspects of drinking were perceived within this framework.

Treatment for alcohol by coding, as developed by Dovzhenko, meant to do exactly that - submit and dominate people who were weak in their passion for alcohol. These methods are further applied by members of the families, wives scolding their husbands, mothers blaming sons for failing their hopes, children 
resenting parents for an unhappy childhood. An alcoholic is quintessentially guilty and an über-dominated individual.

This paper is an attempt to look at things slightly differently by including the interpretation of our interviewees into the analysis. We have argued that despite the fact that alcoholics are 'bullied' individuals, by breaking the code they exercise agency and thus can strategically manipulate the pressure and demands from outside.

********

Slowly walking along the rows at the city market, Artem runs into his old pal whom he has not seen for a long time. Standing at a distance, we can hear their loud exclamations of excitement, punctuated by swearing, and energetic slapping of each other's shoulders. Artem's friend, and his drinking associate in the past, is now at the end of his encoding term. He is in anticipation of a relaxing period and is already planning a party. He says he will take some time off, get back to his pals, drink for a couple of months to his heart's content. His small but lively market business requires attention and he cannot completely abandon it. He will get coded again, surely, but that is later. For now he has other important things to consider.

\section{REFERENCES}

Ahearn, Laura M. 2001. Language and Agency. Annual Review of Anthropology, Vol. 30, pp. 109-137. http://dx.doi.org/10.1146/annurev.anthro.30.1.109.

Brody, Hugh 1977. Alcohol, Change and the Industrial Frontier. Etudes/Inuit/ Studies, Vol. 1, No. 2, pp. 31-46. Available at http://www.jstor.org/ stable/42869285?seq=1\#page_scan_tab_contents, last accessed on May 27, 2015.

Certeau, Michel de 1984. The Practice of Everyday Life. Berkeley: University of California Press. Available at http://danm.ucsc.edu/ dustin/library/de\%20certeau,\%20 the\%20practice\%20of\%20everyday\%20life.pdf, last accessed on May 27, 2015.

Efron, Vera 1960. The Soviet Approach to Alcoholism. Social Problems, Vol. 7, No. 4, pp. 307-315. http://dx.doi.org/10.2307/799327.

Field, Mark G. 1955. Alcoholism, Crime, and Delinquency in Soviet Society. Social Problems, Vol. 3, No. 2, pp. 100-109. http://dx.doi.org/10.2307/798709.

Fleming, P.M. \& Meroyan, A. \& Klimova, I. 1994. Alcohol Treatment Services in Russia: A Worsening Crisis. Alcohol and Alcoholism, Vol. 29, No. 4, pp. 357-362.

Foucault, Michel 1978. The History of Sexuality. Volume 1. Transl. by Robert Hurley. New York: Pantheon Books. Available at http://monoskop.org/images/4/40/ Foucault_Michel_The_History_of_Sexuality_1_An_Introduction.pdf, last accessed on May 27, 2015. 
Foucault, Michel 1989. Madness and Civilization: A History of Insanity in the Age of Reason. London: Routledge.

Foucault, Michel 1995 [1975]. Discipline and Punish: The Birth of the Prison. New York: Vintage Books. Available at http://monoskop.org/images/4/43/Foucault_Michel_ Discipline_and_Punish_The_Birth_of_the_Prison_1977_1995.pdf, last accessed on May 27, 2015.

Herlihy, Patricia 2002. The Alcoholic Empire: Vodka and Politics in Late Imperial Russia. Oxford: Oxford University Press.

Ivanov, Gennady 2012. Kodirovanie v gipnoze. Lechenie alkogolizma, zaikaniia gipnozom (metod Dovzhenko). [Coding by Hypnosis. Treatment of Alcoholism, Stutter by Hypnosis (Dovzhenko's Method).] Available at https://www.youtube.com/ watch?v=BZseTTmnS2I, last accessed on June 3, 2015.

Kharkhordin, Oleg 1999. The Collective and the Individual in Russia: A Study of Practices. Berkeley \& London: University of California Press.

Korolenko, Caesar \& Minevich, Vladimir \& Segal, Bernard 1994. The Politicization of Alcohol in the USSR and Its Impact on the Study and Treatment of Alcoholism. Substance Use and Misuse, Vol. 29, No. 10, pp. 1269-1285.

Magalif, Aleksei 2011. Kodirovanie - lechenie zapretom. [Coding - Treatment by Prohibition.] Available at http://www.youtube.com/watch?v=FRUbdSTNDDw, last accessed on May 27, 2015.

Patrov, Aleksandr 2010. Kodirovanie po Dovzhenko (emotsional'no-stressovaia psikhoterapiia). [Coding by Dovzhenko (Emotional Stress Psychotherapy).] Osvobozhdenie. [Liberation.] Available at http://narcofree.ru/metodi_lecheniya_ alkogolizma/osobennosti_kodirovaniya_po_dovzhenko, last accessed on May 27, 2015.

SakhaPress 2013. Pochti 30 tysiach zhitelei Iakutii stradaiut alkogolizmom i alkogol'nymi psikhozami. [Almost 30 Thousand Residents of Yakutia Suffer from Alcoholism and Alcohol-Related Psychosis.] June 12. Available at http://www.sakhapress. ru/archives/139851, last accessed on May 27, 2015.

Samson, Colin 2003. A Way of Life That Does Not Exist: Canada and the Extinguishment of the Innu. London \& New York: Verso.

Scott, James C. 1990. Domination and the Arts of Resistance: Hidden Transcripts. New Haven: Yale University Press.

Solomon, Susan Gross 1989. David and Goliath in Soviet Public Health: The Rivalry of Social Hygienists and Psychiatrists for Authority over the Bytovoi Alcoholic. Soviet Studies, Vol. 41, No. 2, pp. 254-275. Available at http://www.jstor.org/ stable/152227?seq=1\#page_scan_tab_contents, last accessed on May 27, 2015.

Spicer, Paul 1997. Toward a (Dys)functional Anthropology of Drinking: Ambivalence and the American Indian Experience with Alcohol. Medical Anthropology Quarterly, Vol. 11, No. 3, pp. 306-323. http://dx.doi.org/10.1525/maq.1997.11.3.306.

Transchel, Kate 2006. Under the Influence: Working-Class Drinking, Temperance, and Cultural Revolution in Russia, 1895-1932. Pittsburgh: University of Pittsburgh Press.

Tumusov, Petr 2011. Uspekh Lecheniia - v Formirovanii Chelovecheskoi Voli. [Success of Treatment is in the Formation of Will Power.] Meditsina RF, No. 4 (60). Available at http://www.medicinarf.ru/journals/709/8544/, last accessed on June 3, 2015. 
Tatiana Argounova-Low, Platon Sleptsov

Yurchak, Alexei 2003. Soviet Hegemony of Form: Everything Was Forever, Until It Was No More. Comparative Studies in Society and History, Vol. 45, No. 3, pp. 480-510. http://dx.doi.org/10.1017/S0010417503000239. 